\title{
World Natural Heritage sites and regional development - the cases of Mt Kenya and Mt Kilimanjaro
}

\section{Katharina Conradin, Miriam Chiyumba, Boniface Kiteme, Simon N. Mwaura \& Karina Liechti}

Keywords: World Natural Heritage, effects, tourism, regional development, North-South

\section{Abstract}

The popularity of World Heritage status continues apace - more sites are included in the List every year. World Natural Heritage sites in particular are increasingly discussed as a promising strategy for reconciling conservation and sustainable development. By means of two case studies from East Africa - which are embedded in a global survey on the effects of World Heritage Status - this report analyses what actually happens in situ when World Heritage status is granted to an area. The studies show that the effect of this international conservation status should not be underestimated, especially with regard to institutional aspects.

\section{Profile}

Protected area

Mt Kenya \& Mt Kilimanjaro

Country

Kenya \& Tanzania

\section{Introduction}

As of today, there are 981 World Heritage (WH) Sites worldwide - of which 193 are natural, 759 are cultural and 29 are mixed (UNESCO 2013). While the WH status was originally established as a way of guaranteeing the conservation of the world's most outstanding heritage sites (UNESCO 1972), WH status today raises numerous additional expectations that range from increasing visitor numbers to delivering impulses for regional development. There is broad consensus both in the comprehensive, frequently commissioned reports (Hambrey 2007; PricewaterhouseCoopers 2007; Rebanks 2009) and in scientific articles (Buckley 2004; Li et al. 2008; Wiesmann \& Liechti 2004) - that having WH status also leads to outcomes other than conservation. These findings have been confirmed by the results of a broad survey by the main author of this report. According to these various sources, outcomes of WH status include increased attractiveness for tourism, enhanced conservation, greater leverage for funding, awareness building, education and a raised level of collaboration and public participation. On this basis, protected areas, including WH sites, are increasingly discussed as model regions for sustainable development (Mose 2007). But what do these findings mean in reality? Do the effects of WH status correspond to the development challenges in the regions in question? Two case studies from East Africa, conducted in Kenya and Tanzania, show how WH status has affected Mt Kenya and Mt Kilimanjaro. The studies were based on in-depth interviews and field visits in 2011; the present report draws on the results.

\section{The cases of Mt Kilimanjaro and Mt Kenya}

Both Mt Kilimanjaro and Mt Kenya (Figure 1) were put under protection in the first half of the $20^{\text {th }}$ century due to their ecological functions. World Heritage status increases their protection status.
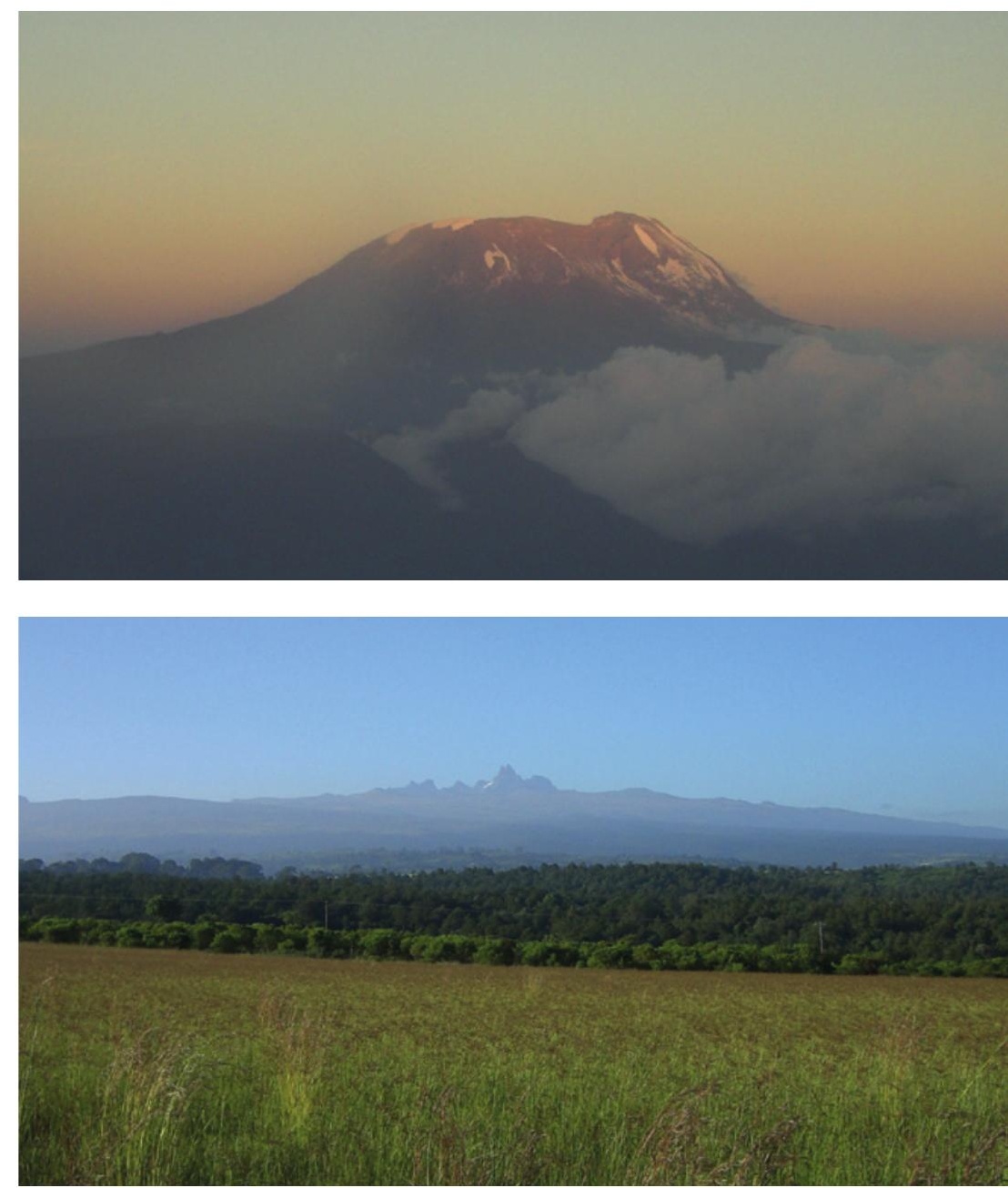

Figure 1 - Both Mt Kilimanjaro (top) and Mt Kenya (bottom) were put under protection in the first half of the $20^{\text {th }}$ century due to their ecological functions. World Heritage status increases their protection status. (C) Katharina Conradin 
At $5895 \mathrm{~m}$ and $5199 \mathrm{~m}$ above sea level, Mt Kilimanjaro and Mt Kenya are the two highest mountains in Africa. Mt Kilimanjaro was declared a World Natural Heritage site in 1987 (World Heritage Committee 2006), based on its superlative natural significance as one of the largest free-standing mountains in the world and its high biodiversity values. Mt Kenya, with its rugged glacier-clad summits, afro-alpine moorland areas and diverse forests - all representing outstanding ecological processes - was inscribed in the list of $\mathrm{WH}$ sites in 1997 (World Heritage Committee 1997).

Both sites have a long-standing tradition of conservation and were declared forest reserves in the first half of the $20^{\text {th }}$ century due to their significance for the regional ecosystems and their function as water towers for millions of people in East Africa. Agriculture remains the single most important economic sector and large segments of society depend directly on agricultural and forest resources for their livelihoods. This, combined with the pressure of high population growth, leads to frequent and often serious conflicts over natural resources, predominantly over water use and access to forest resources. Our case studies show that WH status can have beneficial effects in some contexts, but granting WH status alone is not enough to solve some of the challenges at hand.

\section{Tourism}

Apart from agriculture, tourism is one of the economic mainstays of both regions. Mt Kilimanjaro is one of the tourism highlights of Tanzania, with almost $8 \%$ of all tourists visiting the park (Mitchell et al. 2009). Its popularity can be attributed to both the attraction of Mt Kilimanjaro as the highest peak in Africa and the relative ease of the ascent. Tourism in Kilimanjaro Region is of above-average benefit to the poor population. A relatively recent study (Mitchell et al. 2009) found that almost a third of in-country tourist spending in the Kilimanjaro Region, or USD 13 million per year, reaches poor people directly, making it one of the most successful examples of resource transfer from international tourists to poor people in the locality. Reasons are that it takes several days to climb the mountain, providing a market for the labourintensive guiding and porter business that is often carried out by poorer people, and the fact that food and beverages consumed are sourced from local markets whose suppliers are overwhelmingly local smallholder farmers. While these effects are not clearly attributable to WH status, local statistics show that there has been a considerable increase in visitor numbers after inscription and that the WH label has contributed to the popularity of Mt Kilimanjaro (TANAPA 2011). This increased popularity makes it imperative to have clearer regulations on porters, the number of permitted ascents and the number and quality of accommodation facilities within the national park.

In Kenya, by contrast, visitor numbers did not increase after WH status was granted and only $1 \%$ of all foreign tourists visiting national parks in Kenya opt for Mt Kenya (Ministry of Tourism 2010). This is only partly attributable to the difficulty in reaching the highest point of Mt Kenya. The large game reserves or the coast remain preferred tourist destinations, not least because the country's tourism marketing has neglected alternative forms of tourism such as mountain tourism. Furthermore, the lack of regulations and deficient policies - e. g. with regard to porters, community-based initiatives and inadequate infrastructure - are perceived as major obstacles for developing forms of tourism that benefit the poor.

\section{Biodiversity conservation and local livelihoods}

Both Mt Kenya and Mt Kilimanjaro were pilot regions in the Community Management of Protected Areas Conservation (COMPACT) programme, a UN initiative that aims at fostering sustainable development within and adjacent to protected areas. The programme provides small grants to community-based activities that are intended to strengthen biodiversity conservation while generating local income in particular WH sites and biosphere reserves (Brown et al. 2010). In this way, it also targets poverty as one of the root causes of environmental degradation. Projects in the area include improving land use through contract farming, implementing alternative energy sources, resolving water use conflicts and improving water resource management at the community level. Even if such projects are successful and improve local livelihoods while safeguarding natural resources, they also highlight that it does not suffice to award an international label to an area. Poorer regions in particular continue to depend on support to reach the goals proclaimed in the WH convention.

\section{Institutional collaboration and public participation}

When Mt Kenya was granted WH status, two separate protected areas were formally united: Mt Kenya Forest Reserve, which includes the lower, forested areas of the mountain, and Mt Kenya National Park. The division of responsibilities between the two state organizations was not always easy and frequently led to conflicts about the right conservation approaches. Unifying them has strengthened the conservation status of the site, but its natural resources are still under immense pressure. In the Mt Kenya area, WH status was instrumental in improving collaboration among the different stakeholders as well as public participation, e.g. by the formation of so-called Water Resources Users' Associations or Community Forest Associations. These organizations promote community participation in conservation and management of resources, and have been instrumental in addressing upland - lowland water conflicts.

In the Mt Kilimanjaro region, the COMPACT programme also fostered collaboration among different stakeholders. In addition, the organization Tanzania 
National Parks has a social programme in which $7 \%$ of the budget is invested every year into community projects, such as dispensaries or schools. The social programme benefits from the WH status of Mt Kilimanjaro. However, despite the beneficial effects of community projects for the population, local communities regret not having a say in how this money is spent. Although they welcome health care and education for their children, many would rather see a fund to support community initiatives (tourism, organic farming etc.) that would allow them to compensate the losses they frequently face as a result of the stringent conservation measures that accompany WH status. The local population feels their participation is perceived as a noncommittal consultation rather than true involvement.

\section{Conclusion}

WH status in the Mt Kenya and Mt Kilimanjaro regions has led to positive developments, most importantly by strengthening the conservation status of the two mountains and raising it to an international level. In addition, WH status has contributed to fostering both local and international cooperation and participatory management, which are crucial bases for sustainable management of the available resources. Yet, looking at the effects of WH status in more detail, much remains to be done. In particular, losses incurred by the local population must be taken into account: where traditional utilization (e. g. the use of forest resources) is prevented, local populations must be compensated. International programmes such as COMPACT have a positive influence in this respect and highlight the need to support developing countries in mitigating the critical effects of increased conservation.

Overall, WH status is an opportunity, and has the potential to address some of the challenges that protected areas face today. Yet whether WH status has tangible effects varies among different contexts and depends on the motivations pursued by the various stakeholders, on local stakeholder involvement and ownership, and on the importance ascribed to - and the level of funding granted for - the site's management and protection. These framework conditions generally still receive insufficient attention, which means that many WH sites exist primarily on paper. Last but not least, this is also related to the WH Convention, which still maintains a somewhat unilateral focus on pure conservation, neglecting the fact that successful protection is always embedded in a regional context. Our case studies show that the regions surrounding the WH sites are not always sufficiently integrated into the WH concept. Therefore the WH policy framework should be reformed to view conservation as a necessary and integral part of regional development. More attention must be given to the regions surrounding WH sites, in addition to the actual sites themselves. Only then can the WH Convention achieve its goal: to preserve the most outstanding natural and cultural wonders for generations to come.

\section{Acknowledgements}

This report is based on three case studies carried out for the project Benchmarking World Heritage \& Tourism by the World Nature Forum. The author additionally wishes to acknowledge support from the Swiss National Centre of Competence in Research (NCCR) North-South, co-funded by the Swiss National Science Foundation (SNSF), the Swiss Agency for Development and Cooperation (SDC), and the participating institutions.

\section{References}

Brown, Jessica, A.- M. Currea \& T. Hay-Edie 2010. COMPACT. Engaging Local Communities in Stewardship of Globally Significant Protected Areas. New York: The Global Environmental Facility Small Grants Programme.

Buckley, R. 2004. The effects of world heritage listing on tourism to Australian national parks. Journal of Sustainable Tourism 12 (1): 70-84.

Hambrey J. 2007. Social, economic and environmental benefits of World Heritage sites, Biosphere Reserves, and Geoparks. Perth (GB): Scottish Natural Heritage Commissioned Report NO. 248 (ROAME No. F06NC05).

Mimi, L., B. Wu \& L. Cai 2008. Tourism development of World Heritage sites in China: a geographic perspective. Tourism Management 29 (2): 308-319.

Ministry of Tourism. 2010. Visitor Arrival and Parks Statistics. Nairobi: Ministry of Tourism

Mitchell, J., J. Keane \& J. Laidlaw 2009. Making Success Work for the Poor: Package Tourism in Northern Tanzania. Arusha: Netherlands Development Office (SNV).

Mose I. 2007. Protected areas and regional development in Europe: Towards a new model for the $21^{\text {st }}$ century. Ashgate Studies in Environmental Policy and Practice.

PricewaterhouseCoopers 2007. The Costs and Benefits of World Heritage Site Status in the UK. Full Report. Prepared for the Department for Culture, Media and Sport (DCMS), CADW and Historic Sctotland. London: DCMS.

Rebanks 2009. World Heritage status: is there opportunity for economic gain? Research and analysis of the socio-economic impact potential of UNESCO World Heritage site status. Penrith.

TANAPA 2011. Kilimanjaro national park visitor statistics. Moshi: Tanzania National Parks Authority.

UNESCO 1972. Convention concerning the protection of the world cultural and natural heritage. Adopted by the general conference at its seventeenth session in Paris, $16^{\text {th }}$ November 1972.

UNESCO 2013. World Heritage List. Available at: http://whc.unesco.org/en/list/ (accessed on 15/08/2013)

World Heritage Committee 2006. Mt Kilimanjaro national Park. Available from http://whc.unesco.org/ en/list/403 (accessed on 02/11/2011) 
Wiesmann, U. \& K. Liechti. 2004. The contributions of World Natural Heritage sites to sustainable regional development - two case studies from the North and the South. Journal of Alpine Research 92 (3): 84-94.

World Heritage Committee 1997. Mt Kenya National Park / Natural Forest World Heritage Site. Available at: http://whc.unesco.org/en/list/800 (accessed on $17 / 10 / 2011)$

\section{Authors}

\section{Katharina Conradin}

has studied geography, sustainability studies and English linguistics and is currently writing her $\mathrm{PhD}$ thesis on World Heritage Sites and sustainable regional development at the University of Bern, Switzerland. She is the director of Mountain Wilderness Switzerland, an Alpine environmental NGO.

\section{Miriam Chiyumba A.}

is a researcher with the Centre for Training and Integrated Research in Arid and Semi-Arid Lands Development (CETRAD) and postgraduate student currently writing her thesis on Mountain tourism and its contribution to regional development in Mt Kenya at the University of Nairobi, Kenya. Her background is in urban and regional planning, tourism and wildlife management.

\section{Boniface Kiteme}

$\mathrm{PhD}$, is the Director of the Centre for Training and Integrated Research in Arid and Semi-Arid Lands Development (CETRAD). He is a senior research associate of the University of Berne and has worked in the field of sustainable development for most of his professional life.

\section{Simon N. Mwaura}

has studied agricultural economics, development studies and agribusiness and is currently assistant lecturer at Mount Kenya University, Kenya, in the School of Business and Public Management.

\section{Karina Liechti}

is a human geographer and a senior research scientist at the Centre for Development and Environment CDE, University of Bern, Switzerland. Her areas of interest are common property land-use systems, landscape change and regional development, with a specific focus on World Heritage Sites. 